\title{
Soil Atlas of Europe
}

(Európa Talaj Atlasza)

(European Commission - European Soil Bureau Network, 2005)

Az Atlasz a lassan földrajzi Európává bővülő Európai Unió egyik jelentős, az egységet szimbolikusan is tükröző, szép kiadványa. Eredetileg az EU tíz új tagországgal, (köztük Magyarországgal) történő 2004. május 1-jei bővülésének időpontjára tervezett megjelenése ugyan egy évet csúszott, de ez mit sem von le össz-európai együttmüködést kifejező tartalmából, s kiadásának aktualitásából.

A 128 oldalas Atlasz föszerkesztői - Arwyn Jones, Luca Montanarella és Robert Jones - 21 ország és 4 nemzetközi szervezet 50 társszerzőjének munkáját koordinálták egy 30-tagú szerkesztőbizottság segítségével. Az Atlasz 34 ország adatbázisára épült, előzményként pedig Európa 1:2,5 000000 (1:2,5M) méretarányú FAO Talajtérképére (1965), a FAO/UNESCO 1:5M méretarányú Világ Talajtérképére (1980), Európa 1:1M méretarányú Talajtérképére (1985), valamint a Közös Kutatási Központ (Joint Research Centre, JRC) Európai Talajtani Iroda Hálózatának (European Soil Bureau Network, ESBN) legutóbbi években megjelent kiadványaira támaszkodott. Az Atlasz elkészítésének több mint tíz évig tartó munkájában kezdettől fogva jelentős és eredményes munkát végzett Michéli Erika és Várallyay György, mint társszerző, szerkesztőbizottsági tag, valamint az ESBN Tudományos Tanácsadó Testületének tagja. Az Atlaszba beépülö magyar talajtani adatbázisok és fényképanyag rendelkezésre bocsátásával azonban természetesen egy széleskörü hazai talajtanos szakembergárda érezheti magát joggal az Atlasz társszerzőjének, közremüködőjének. Az Atlasz megjelentetésében történő magyar részvétel tovább erősítette tudományterületünk eddig is elismert nemzetközi presztízsét.

Az Atlasz szerkesztésének alapvető irányelve az az Einsteintől származó gondolat volt, hogy a talajt olyan egyszerüen kell bemutatni, ahogy csak lehet, de nem egyszerübben! Ezt szem előtt tartva épült fel az Atlasz szerkezete, különös figyelmet fordítva az egyszerü, közérthető, de pontos és szabatos fogalmazásra, valamint a tartalom gazdag illusztrálására. Az Atlasz ily módon jóval több, mint egy egyszerü „térkép-tár”, hanem egy kitünő, a talajt és környezetét bemutató oktatási anyag, igényes népszerüsítő kiadvány, amit minden érdeklődő ember élvezettel forgathat, tanulmányozhat.

Az Atlasz Előszavában az EU Környezetvédelmi, valamint Tudományos Kutatási Főigazgatósága, a JRC, továbbá az ESBN vezetői egyaránt kiemelték az Atlasz megkülönböztetett jelentőségét az EU Tematikus Talajvédelmi Stratégiájának megalapozásában, a talaj és a környezet állapota iránti társadalmi aggódás felkeltésében és felerősítésében, a fenntarthatóság elvét szem előtt tartó tudatformálásban, amelyben az Atlasz híd szerepét töltheti be a (talajtani) szakemberek, döntéshozók, politikaformálók és a társadalom között. Hangsúlyozták, hogy egy közös (az élelmiszerbiztonság és a környezet- 
minőség szempontjait egyaránt figyelembe vevő) Európai Talajvédelmi Stratégia megvalósítása csak akkor lehet eredményes, ha figyelembe veszi a természeti adottságok, mindenekelött ezek integrált összhatását tükröző talajviszonyok regionális, sőt lokális sokféleségét, amelynek bemutatása az Atlasz egyik célkitüzése.

Az Atlasz Bevezetése példamutató egyszerüséggel és ugyanakkor követendő precizitással mutatja be a talajt, mint természeti képződményt, mint négydimenziós, négyfázisú, polidiszperz rendszert. Rámutat jelentőségére és multifunkcionalitásának fontosságára: élelmiszer, ipari nyersanyag- és energia célú biomassza előállításának alapvető közege; az élővilág primér tápanyagforrása; a természet hatalmas szürő, puffer és detoxikáló rendszere; élöhely és termőhely; természeti és történelmi örökségek megőrzője; a társadalmi fejlődés infrastruktúrájának hordozója, szó szerinti építőköve. Kitünő összefoglalást találunk a talajképződés tényezőiről és legfontosabb folyamatairól: mállás, humuszképződés, kilúgzás, agyagmozgás, agyagszétesés, glejesedés, láposodás, sófelhalmozódás/szikesedés. Ezekből vezetik le a szerzők a talajszelvény kialakulását, rétegzettségének „ABC”-jét, szekvenszeit. A népszerüsítő közérthetőséget jól szolgálják a szövegbe szerkesztett, ügyesen kiemelt „definíció-ablakok”, valamint a kert talaját bemutató, a talaj és a mezőgazdaság, a talaj és a kulturális örökség összefüggéseit szemléletes fényképekkel illusztráló tömör összefoglalás.

A következő fejezet Európa talajait mutatja be, mégpedig osztályozás tekintetében főként a WRB-re (World Reference Base, Világ Talajreferencia Bázisa) alapozva. Külön kiemelésre érdemes a talajosztályozási rendszerek, így tulajdonképpen az egész Atlasz megértését nagyon jól elősegítő „,minősítő-karakter” (qualifier) lista, valamint a feltalaj- és altalajhorizontokat, továbbá a diagnosztikai jellemzőket felsoroló összefoglalás - rövid és pontos definíciókkal. Ezután következik Európa föbb talajtípusainak bemutatása. Mégpedig tömören, az alábbiakat tartalmazó egységes szerkezetben: megnevezés; definíció; a környező tájat, illetve a talajszelvényt bemutató remek fénykép; ill. az európai elterjedést bemutató térképvázlat. A bemutatott 24 fótípus a következö (a megnevezés utáni zárójelben lévő első szám a \%-os európai elterjedést, a második szám az Atlasz térképanyagán megjelenő altípusok számát fejezi ki):

$\begin{array}{llll}\text { Acrisols } & (<1 \% ; 3) & \text { Histosols } & (5 \%, 3) \\ \text { Albeluvisols } & (15 \%, 5) & \text { Kastanozems } & (2 \%, 4) \\ \text { Andosols } & (1 \%, 5) & \text { Leptosols } & (9 \%, 8) \\ \text { Anthrosols } & (<1 \%, 2) & \text { Luvisols } & (6 \%, 15) \\ \text { Arenosols } & (1 \%, 6) & \text { Phaeozems } & (3 \%, 10) \\ \text { Calcisols } & (5 \%, 3) & \text { Planosols } & (<1,4) \\ \text { Cambisols } & (12 \%, 20) & \text { Podzols } & (14 \%, 9) \\ \text { Chernozems } & (9 \%, 8) & \text { Regosols } & (2 \%, 4) \\ \text { Cryosols } & (2 \%, 2) & \text { Solonchaks } & (<1 \%, 2) \\ \text { Fluvisols } & (5 \%, 9) & \text { Solonetzes } & (<1 \%, 4) \\ \text { Gleysols } & (5 \%, 12) & \text { Umbrisols } & (2 \%, 4) \\ \text { Gypsisols } & (<1 \%, 1) & \text { Vertisols } & (<1 \%, 8)\end{array}$

Ugyancsak remekül szemléltetett a talajtérképezést ismertető rész, az „örök” léptékprobléma megközelítésétől kezdve a talajtérképezés egyes lépéseinek gazdagon illusztrált bemutatásáig, a helyszíni felvételezéstől és a mintavételtől kezdve a digitális talajtérképezésig. 
A következő fejezet Európa talajtérképeiről közöl történeti, tematikai és tartalmi áttekintést. Ez a rész tartalmazza a 24 fötípus, valamint a regionális térképeken megjelenő 148 típus színkulcsát és betüjelét is. Ez utóbbiakra feltétlenül szükség van a térképeken elhatárolt foltok azonosításánál, hisz ennyi színárnyalatot még a legjobb szem sem tud megkülönböztetni, nem is beszélve a színek használat közbeni fakulásáról. Az azonosító betüjelek beírása ugyanakkor számos esetben okozhatott gondot a szerkesztőknek, hisz néhány adatszolgáltató nem vette figyelembe az elhatárolt foltok minimális méretére vonatkozó szabályt és a „kevesebb több lenne” alapelvet, s a térkép „pontosságát” és „részletességét” a térkép léptéke által megkövetelt foltméretnél kisebb térképezési egységek feltüntetésével igyekezett kifejezni. Emiatt sajnos az Atlasz térképeinek egy részénél indokolatlanul (nem a természeti viszonyok és talajviszonyok eltéréséből adódóan) is látszanak az országhatárok - egyszerúen az elhatárolt térképfoltok nagysága alapján. Egy 1:10M méretarány körüli generalizált Európa talajtérkép bemutatását követően közli az Atlasz az alaptartalmat képező talajtérkép-anyag hálózatát. Érdekes és jellemző aktualitású volt az a vita, amelynek alapján végül is az alkalmazott módszer kialakult. A térképanyag bemutatására ugyanis elvileg három lehetőség adódott: a) országonként; b) földrajzi régiónként; c) szisztematikus térképlaponként. Az utóbbi két esetben dilemmát jelentett a régiók, ill. térképlapok elnevezése, megjelölése is. Hisz egy-egy körzetben vagy térképlapon természetesen több ország szerepel, mégpedig különböző arányban, nagyságban. Ugyancsak kérdést jelentett, hogy a teljes terület azonos - egységesen 1:1M - méretarányban kerüljön bemutatásra, vagy az egyes országok nagyságától, ill. adatbázisának részletgazdagságától függő, különböző léptékekben. Hosszú viták után alakult ki a végül megvalósított variáns, mégpedig Európa Autóatlaszának megoldásához hasonlóan: számmal jelölt térképlapok, s az adott terület természetföldrajzi, elsősorban talajtani heterogenitásától, ill. a rendelkezésre álló megbízható adatbázis részletességétől függő lépték; s csak halvány országhatárok. Így az Atlasz ténylegesen az össz-európai együttmüködés egyik szép szimbólumává, jól időzített példájává vált.

Európa talajait 17 térképlap mutatja be. Ezek közül $5 \mathrm{db}$ 1:1,5 M, $1 \mathrm{db}$ 1:1,75 M, 1 db 1:2 M, $1 \mathrm{db}$ 1:2,2 M, $7 \mathrm{db}$ 1:2,5 M, $1 \mathrm{db}$ 1:3 M és $1 \mathrm{db}$ 1:6,5 M méretarányú. Mindegyik térképlaphoz rövid magyarázó szöveg is tartozik, amely „dióhéjban” ismerteti a régió természetföldrajzát, föbb talajait, talajhasználatának jellemzőit és problémáit.

A következő fejezet Európa talajait globális környezetbe helyezi. Bemutatja a Föld talajtérképét (33 kategória), Eurázsia talajtérképét $(1: 20 \mathrm{M})$, majd régiónként Európa más kontinensekkel közös néhány régiójának (Mediterrán térség, Északi-sarkhoz közeli övezetek) talajait.

Az Európa talajtani adatbázisait összefoglaló fejezet röviden és logikus didaktikai felépítésben írja le a talajról - különböző forrásokból - szerzett információk adatbázisba szervezésének módszereit, az adatbázisok tartalmát, valamint a geoinformációs rendszerek ez irányú felhasználási lehetőségeit. A méretaránynak megfelelően igen vázlatos „mini-térképeken” kerültek bemutatásra Európa talajainak legfontosabb fizikai és kémiai tulajdonságai, valamint - különböző méretarányú tematikus térképeken - néhány gyakorlati alkalmazási lehetőség: pl. agroökológiai potenciál; egyes növények termesztésére való alkalmasság; a víz és/vagy szélerózió által okozott talajveszteség; az $\mathrm{NO}_{2}-$ emisszió mértéke. A fejezet az ESB-nek, ill. össz-európai regionális hálózatának (ESBN) bemutatásával zárul, felsorolva ezek sokoldalú tevékenységét, beleértve olyan nemzetközi projekteket, mint az EUSIS (European Soil Information System), INSPIRE 
(INfrastructure for SPatial InfoRmation in Europe), SOTER (SOil and TERrain Digital Database) vagy a talajminőség változásának monitorozása.

A „Talajt fenyegető veszélyek Európában” címü fejezet az Atlasz gyakorlati hasznosítása szempontjából talán a legfontosabb rész, hisz célja az EU Tematikus Talajvédelmi Stratégiájának megalapozása. Sajnos, a talajt fenyegető veszélyek köre egyre szélesebb, a fenyegetettség pedig egyre súlyosabb. A számos probléma közül az Atlaszban - a Talajvédelmi Stratégiában is szereplö - nyolc legfontosabb veszély kerül bemutatásra: 1. Talajfedés (soil sealing), a településekkel, infrastruktúrával vagy az általános társadalmi fejlödés gyakorlatilag kivédhetetlen, csak racionálisan mérsékelhető következményeivel. 2. Víz és/vagy szél okozta erózió. 3. Talaj szervesanyag-tartalmának csökkenése. 4. Biodiverzitás csökkenése. 5. Talajszennyez(öd)és. 6. Talajtömörödés. 7. Hidrogeológiai kockázatok növekedése. 8. Sófelhalmozódás, szikesedés. A nyolc veszélyt egy-egy oldal mutatja be az Atlaszban, pontos definíciókkal, ok-feltáró elemzésekkel, szemléletes fényképekkel és térképekkel. A 8. témának Várallyay György volt szerzője és szerkesztője, a 7.-nek pedig társszerzője.

„A talajok védelme az Európai Unióban” címü fejezet jó illusztrációja az eddigi tevékenységnek, valamint a jövőbeni feladatoknak. Ugyancsak remekül illusztrált az „Egyéb információk” fejezet is, amely tulajdonképpen a talajképződési tényezők (domborzat, geológiai viszonyok, hömérséklet- és csapadékviszonyok, növényzet, talajhasználat) térképi bemutatása.

Az Atlasz anyagát részletes publikációs lista egészíti ki, lehetővé téve az érdeklődők számára a további „,búvárkodást”. A lista nemcsak az „össz-európai” publikációkat tartalmazza, hanem a közremüködő országok talajviszonyaira vonatkozó részletesebb információkat közzé tevő munkákat is. Jelentős mértékben megkönnyíti az Atlasz használatát, elsősorban az oktatásban, nevelésben, ismeretterjesztésben és tudatformálásban történő felhasználását, a talajtani kifejezések értelmező kisszótára. A szerzők, ill. ESBN szakértők „elérhetőségének” közreadása pedig közvetlen párbeszédre és jövőbeni együttmüködésre nyújt lehetőséget.

Az Atlasz ünnepélyes bemutatójára 2005. október 18-án került sor Londonban, nemcsak a vendéglátó Egyesült Királyság, hanem több más ország és szakterületileg illetékes nemzetközi szervezet magasrangú képviselőjének jelenlétében és méltatásával, valamint a társszerzők és közremüködők szinte teljes körének a részvételével. A bemutatót ugyanis a szervezők az ESBN Szakértői Plenáris ülésével kötötték egybe.

Az Atlasz tartalmával és igényes kivitelével eredményesen tölt(het)i be „,misszionáriusi" szerepét a társadalom talaj iránti érdeklődésének felkeltésében, multifunkcionális szerepének megismertetésében, fenntartható használata, megőrzése és értékmegóvása szükségességének elismertetésében, s a közös Európai Talajvédelmi Stratégia megvalósításában. Reméljük sok kézbe odakerül, s inspirál alkotó gondolatokat, serkent tenni akarásra, s cselekvésre.

VÁRALLYAY GYÖRGY

Postai cim: VÁRALLYAY GYÖRGY, MTA Talajtani és Agrokémiai Kutatóintézet, 1022 Budapest, Herman Ottó út 15.E-mail: g.varallyay@rissac.hu 